\title{
Enterotoxigenicity Assessment of Escherichia coli and Salmonella spp. isolated from snails and Zobo Drink using suckling albino rats
}

\author{
Asiton-a Asifamabia Dick (Corresponding Author) \\ Science Laboratory Technology Department \\ School of Science and Technology \\ Captain Elechi Amadi Polytechnic, Rumuola \\ P.M.B. 5936, Port Harcourt, Nigeria. \\ 08064131848,08055673874 \\ drasitonad@yahoo.com, asitona2016@yahoo.com \\ Amudatu Ambali Adedokun \\ Department of Biology, \\ Ignatius Ajuru University of Education \\ Port Harcourt, Nigeria \\ amudatu.adedokun@iaue.edu.ng, amudatuadedokun@gmail.com
}

\section{Evelyn Orevaoghene Onosakponome \\ Department of Medical Laboratory Science \\ Pamo University of Medical Sciences, \\ Port Harcourt, Nigeria \\ eonosakponome@pums.edu.ng}

DOI: $10.31364 / \mathrm{SCIRJ} / \mathrm{v} 8 . \mathrm{i5} .2020 . \mathrm{P} 0520770$

http://dx.doi.org/10.31364/SCIRJ/v8.15.2020.P0520770

\begin{abstract}
This study was carried out to investigate the enterotoxigenic profile of Escherichia coli obtained from Zobo drinks and Snail samples and Salmonella spp. obtained from a Poultry farm in suckling albino rats. For the study a total of 30 suckling albino rats were obtained from the Animal Department, University of Port Harcourt, Choba. The suckling albino rats were used to evaluate the enterotoxigenicity potentials of the Escherichia coli isolates (Zobo drink 1, Zobo drink 2, snail sample 1, snail sample 2) and Salmonella spp. (S1, S2, S3, S4) using Gut/body ratio (G/B) and fluid accumulation ratio (FAR). The results after 4 hours shows that the fluid accumulation ratio as follows: Zobo drink 1 (0.050), Zobo drink 2 (0.090), snail 1 (0.087), snail 2 (0.099) and S1 (0.099), S2 (0.080), S3 (0.122), S4 (0.124), indicating toxicity potential of the test isolates, except Zobo drink 1 considering the $>0.065$ Fluid Accumulation Ratio. The practice of good hygiene, proper cooking of food and adequate enlightenment is strongly recommended.
\end{abstract}

Keywords: Enterotoxicigencity, Escherichia coli, Zobo, Snail, Salmonella spp

\section{Introduction}

Zobo drinks are traditional non-alcoholic beverage which is consumed in most part of Nigeria, mostly in northern part of Nigeria (1). The economic and religious situation in Nigeria has made the zobo drink gain wide acceptance in different occasions. It is used as refreshment, entertainment in parties or as appetizers before the main dish is served and it is also sold in market at a cheaper rate and also to different consumers.

WwW.scirj.org

(C) 2020, Scientific Research Journal

http://dx.doi.org/10.31364/SCIRJ/v8.i5.2020.P0520770

This publication is licensed under Creative Commons Attribution CC BY. 
Zobo drink is a very red liquid drink and taste like fruit punch, it contains vitamin A, riboflavin, niacin, calcium, and iron and it has low sugar, among others it is used in curing minor stomach ailments, sore throat and strengthening the heart among other uses (2).

Apart from the conventional sources of protein; which are mainly meat and fish, snails (molluscs) are excellent sources of protein and mineral elements for many families. Snail meat is a nutritious food that is high in protein, low in fat and a good source of iron (3). The close contact of wild snails with soil and their uncontrolled feeding pattern make the snail susceptible to microbial contamination (4). Snails inherently have high populations of indigenous bacteria and coliforms and other poisonous substances which they ingest (5). Escherichia coli a facultative, anaerobic, Gram-negative rod that lives in the intestinal tracts of animals. Physiologically, Escherichia coli is versatile and well-adapted to its characteristic habitats (6). Escherichia coli consistently inhabit the human intestinal tract, and is an organism that predominantly lives in the human gastrointestinal tract; however, it constitutes a very small proportion of the total bacterial content. The regular presence of Escherichia coli in the human intestine and feaces has led to tracking the bacterium in nature as an indicator of faecal pollution and water contamination. A study by Adebayo-Tayo et al. (7), on the microbiological composition of snails also indicated the presence of Proteus spp., Shigella flexneri, Staphylococcus aureus, Escherichia coli etc. As such, it is taken to mean that, wherever Escherichia coli is found, there may be faecal contamination and the possible presence of intestinal parasites in humans.

It has been reported that salmonellosis which is caused by Salmonella spp. is a veterinary and public health problem of major importance (8); this is most prevalent diseases in poultry birds, which cause huge losses in the poultry business, with a corresponding high socio-economic impact (9). Poultry birds are always been reported as a mode of salmonellae contamination and chicken carcasses and droppings are have implicated by most studies $(10,11)$.

Most Escherichia coli strains are harmless, but some serotypes can cause serious food poisoning in humans, and are occasionally responsible for product recalls due to food contamination (12). The harmless strains are part of the normal flora of the gut, which can benefit their hosts by producing Vitamin K (13) and by preventing the establishment of bacteria within the intestine (14). Symptoms of Escherichia coli include diarrhoea, abdominal pain and fever.

It can be caused by improper food handling, contaminated water, and contact with infected persons or animal (15); the occurrence of the Escherichia coli in Zobo drink and in snail meats indicates contamination which is of public health importance (16). Since the populace enjoys drinking Zobo as well as enjoys the delicacy of snail, there is the need to assess the organisms isolated from the food items. The study is therefore necessary to assess the fluid accumulation ratio of Escherichia coli isolates obtained from Zobo drink and snail meat.

\section{Materials and Methods}

The study was carried in the Department of Science Laboratory Technology, Captain Elechi Amadi Polytechnic, Rumuola, Port Harcourt, Rivers State.

Freshly prepared nutrient agar plates were used to subcultured confirmed Escherichia coli isolates obtained from Zobo drink and snail samples by streaking and incubated for 24 hours at $37^{\circ} \mathrm{C}$. The growth on subculture plates were scooped into a test-tube containing distilled water and the turbidity was compared to Macfarland standard.

Enterotoxigenicity tests were carried out with a modification of (17) and (18). The suckling rats (1-3 days old) were separated from their mothers shortly before the test and placed randomly in groups of five (5), where the first group was inoculated with distilled water as control, the second and third groups were inoculated with Escherichia coli obtained from Zobo drink samples, while the

WwW.scirj.org

(C) 2020, Scientific Research Journal

http://dx.doi.org/10.31364/SCIRJ/v8.i5.2020.P0520770

This publication is licensed under Creative Commons Attribution CC BY. 
fourth and fifth group were inoculated with Escherichia coli from snail samples. For each of the culture (Escherichia coli) obtained from Zobo drink and snail sample, three rats each was inoculated orally with $1 \mathrm{ml}$ of the different cultures using syringe without the needle. All the inoculated animals were kept at room temperature $\left(25^{\circ} \mathrm{C}\right)$ for four (4) hours after which they were killed. The gut (intestine) was surgically removed from the body and each of the intestines was weighed and the body was also weighed and recorded. The fluid accumulation ratio (FAR) of (weight of entire intestine/total body weight-weight of intestine) each animal was calculated. If the gut-to-body weight ratio is $>0.065$, it is significant for enterotoxigenicity.

\section{Results}

The enterotoxigenicity test of the isolates using the suckling albino rate is shown in Table 1. The table contains the source of isolates, mean intestine weight, fluid accumulation ratio and the significance of the results. The results shows the fluid inoculation ratio in Zobo drink 1 is 0.050 , in Zobo drink 2 it is 0.090 ; in snail 1 is 0.087 , and in snail 2 is 0.099 .

The enterotoxigeniocity of the Salmonella spp. isolates using suckling albino rats is shown in Table 2. When the Gut/body ratio (G/B) is greater than 0.065 , the isolates is significant for enterotoxin. The present study showed that (S1, S2, S3, S4) were significant for enterotoxin after 4 hours.

Table 1 Enterotoxigenicity of Escherichia coli obtained from snails and zobo drinks samples

\begin{tabular}{llccc}
\hline $\begin{array}{l}\text { Source of } \\
\text { Isolate }\end{array}$ & $\begin{array}{l}\text { Mean } \\
\text { intestine weight }\end{array}$ & $\begin{array}{l}\text { Mean body weight } \\
- \text { Mean intestine } \\
\text { weight }\end{array}$ & $\begin{array}{l}\text { Gut weight/ Body } \\
\text { weight }\end{array}$ & Result \\
\hline Zobo Drink 1 & 0.266 & 5.300 & 0.050 & - \\
Zobo Drink 2 & 0.533 & 5.900 & 0.090 & + \\
Snail 1 & 0.433 & 4.933 & 0.087 & + \\
Snail 2 & 0.466 & 4.667 & 0.099 & + \\
Control & 0.340 & 6.933 & 0.049 & - \\
\hline
\end{tabular}

- Non-toxicity

$+\quad$ Doubtful toxicity

$+\quad$ Clear toxicity

Table 2 Enterotoxigenicity of Salmonella isolates obtained from the Poultry Farm

\begin{tabular}{|c|c|c|c|c|}
\hline $\begin{array}{l}\text { Isolate } \\
\text { Code }\end{array}$ & $\begin{array}{l}\text { Mean } \\
\text { intestine weight }\end{array}$ & $\begin{array}{l}\text { Mean body weight } \\
\text { - Mean intestine } \\
\text { weight }\end{array}$ & $\begin{array}{l}\text { Gut weight/ Body } \\
\text { weight }\end{array}$ & Result \\
\hline
\end{tabular}

\begin{tabular}{lllll}
\hline S1 & 0.804 & 8.112 & 0.099 & +
\end{tabular}




\begin{tabular}{llccc}
\hline S2 & 0.510 & 6.309 & 0.080 & + \\
S3 & 0.030 & 7.561 & 0.122 & + \\
S4 & 0.924 & 7.423 & 0.124 & + \\
Control & 0.471 & 8.010 & 0.588 & - \\
\hline
\end{tabular}

If $\mathrm{G} / \mathrm{B}>0.065$, It is significant for enterotoxigenicity

+ Positive

- Negative

\section{Discussion}

There is significant enterotoxin production by Escherichia coli after 4hours exposure to the suckling albino mice. This shows that the organism has the potential of producing heat stable enterotoxin (19).

The significant production of enterotoxin by isolates (Zobo sample 2, snail sample 1 and snail sample 2) after 24 hours oral inoculation in albino suckling mice, agrees with the finding of (20). The ability of these isolates to produce toxins after being tested for 4 hours could be attributed to the multiplication of the isolates in the intestinal loop of the mice and production of more colonisation factors and toxins that might alter the host-bacterium interaction (21). The inability of Zobo sample 1 could be that mechanisms other than production of enterotoxin are responsible for their pathogenic activity, although the isolate are from food samples which were contaminated either by environmental factors (22).

Modern researches have revealed that the Escherichia coli pathogenesis is due to a variety of virulence factors caused by different pathological processes (23). Endotoxin is a virulence factor, especially in the process of sepsis. It is divided into two categories: heatlabile enterotoxin (LT) and heat-stable enterotoxin (ST). LT can promote intestinal mucosal cell secretion, resulting in diarrhea and dehydration; ST can increase full Gut Mucosal production (GMP), causing secretory diarrhea. Escherichia coli can cause dehydration and electrolyte imbalance, significant diarrhea, and decreased weight gain in mice (23). Salmonella spp. is one of the leading cause of food poisoning in humans and an important cause of various diseases of livestock resulting in high morbidity and mortality (8). Khanam et al. (2018). It is also reported that the presence of these organisms, their parts which includes bacterial toxin or poisonous protein in certain foods can cause foodborne illness and as well as being responsible for spoilage of food (24).

\section{Conclusion}

Most of the studied Escherichia coli isolates exhibited significant enterotoxigenicity potentials among the infected suckling mice of which especially isolate from snail sample 2 and all the Salmonella isolates from the poultry farm proved to be most enterotoxigenic after 4hours. The study strongly recommends practice of good hygiene, proper cooking of food and adequate enlightenment and education especially as snail meat and Zobo drinks are considered as delicacies in Nigeria.

\section{REFERENCES}

WwW.scirj.org

(C) 2020, Scientific Research Journal

http://dx.doi.org/10.31364/SCIRJ/v8.i5.2020.P0520770

This publication is licensed under Creative Commons Attribution CC BY. 
Osuntogu, B. and Aboaba, O. O. (2004). Microbiological and physico-chemical evaluation of some non-alcoholic beverages. Pakistan Journal of Nutrition, 3:188-192.

Olawale A. S. (2011). Studies in concentration and preservation of sorrel extract. African Journal of Biotechnology, 10(3): 416-423.

USDA (2006). National Nutrient Standard Reference.

http://www.ars.usda.gov/Services/docs.htm. Retrieved: 12/10/2018.

Nyoagbe, L. A., Appiah, V., Nketsia-Tabiri, J. Larbi, D. and Adjei, I. (2016). Evaluation of African giant snails (Achatina and Archchatina) obtained from markets (wild) and breeding farms. African Journal of Food Science, 10(7): 94-104.

International Commission on Microbiological Specifications for Foods, ICMSF (2005). Microorganisms in Foods. 2nd ed, Kluwer Academic/ Plenum Pub. New York. Ch. 6. pp. 84-86.

Todar, K. (2006). Pathogenic E. coli. http//:textbook of bacteriology.net/e.coli.html. Retrieved: 9/7/2018.

Adebayo-Tayo, B. C., Onilude, A. A. and Etuk, F. I. (2011). Studies on Microbiological, Proximate Mineral and Heavy Metal Composition of Freshwater Snails from Niger Delta Creeks in Nigeria. Australia Journal of Technology, 14(4): 290-298.

Obi, O. J. and Ike, A. C. (2015). Prevalence and Antibiogram Profile of Salmonellae in Intensive reared and Backyard Chickens in Nsukka Area, Nigeria. Nigerian Journal of Biotechnology, 30: 18-25.

Foley, S. N., Lynne, A. M. and Nayak, R. (2008). Salmonella Challenges: Prevalence in swine and poultry and potential pathogenicity of such isolates. Journal of Animal Science, 89: E149-E162.

Fashae, K., Ogunsola, F., Aarestrup, F. M. and Hendriksen, R. S. (2010). Antimicrobial susceptibility and serovars of Salmonella from chickens and humans in Ibadan, Nigeria. Journal of infections in Developing Countries, 4: 484-494.

Hassanein, R., Hassan Ali, S. F., Abd El-Malek, A. M., Mohammed, M. A. and Elsayh, K. A. (2011). MultiAntibiotic Resistance of Some Gram Negative Bacterial Isolates from Poultry Litters of Selected Farms in Benue State. International Journal of Science and Technology, 2: 543-548.

CDC (2012). National Center for Emerging and Zoonotic Infectious Diseases. http://www.CDC.gov/fungus/aspergillosis.html. Retrieved 12/09/2018.

Bentley, R. and Meganathan, R. (1982). "Biosynthesis of vitamin K (menaquinone) in bacteria". Microbiol. Rev. 46 (3):241-80.

Reid, G., Howard, J., and Gan, B. S. (2001). "Can bacterial interference prevent infection?". Trends Microbiol. 9 (9): 424-428.

Pietranegelo, A. (2017). What is an intestinal infection due to Escherichia coli? Healthline. www.healthline.com/health/e-coli-infection. Retrieved: 9/8/2018.

Www.scirj.org

(C) 2020, Scientific Research Journal

http://dx.doi.org/10.31364/SCIRJ/v8.i5.2020.P0520770

This publication is licensed under Creative Commons Attribution CC BY. 
Hiko, A., Asrat, D. and Zewde, G. (2008). Occurrence of Escherichia coli 0157.117 in retail raw neat products in Ethiopia. The Journal of Infection in Developing Countries, 2(5): 389-393.

Dean, A. G., Ching, Y. C., Williams, R. Q. and Harden, L. B. (1972). Test for Escherichia coli enterotoxin using infant mice: application in a study of diarrhoea in children in Honolulu. Journal of Infection and Diseases, 135: 407-411. Achatina achatina in Nigeria. Antonie van Leeuwenhook, 46: 475-481.

Arora, D. R. and Arora, B. B. (2008). Textbook of Microbiology. 4th edition. CBS Publisher, New Delhi, India. pp 40-49.

Balaban, N. and Rasooy, A. A. (2000). Staphylococcal enterotoxins. International Journal of Food Microbiology, 61: $1-10$.

Murray, R. J. (2006). Recognition and management of Staphylococcus aureus and Salmonella toxin medicated diseases. International Medical Journal, 2005(2): 106-119. species isolated from well and river water sources in Oproama town in the Niger Delta, Nigeria. Suckling Albino mice. Journal of Natural Sciences Research, 7(14): 2234-3186. Technology, 19(2): 333-340. 